\section{Variability case study based on in-situ rebound hardness testing of concrete Part 2. Statistical analysis of spatial variability parameters}

AdorJÁn BOROSNYÓI - Assoc. Prof., BME, Dept. of Construction Materials and Engineering Geology

- borosnyoi.adorjan@epito.bme.hu

Received: 28. 08. 2014. " Érkezett: 2014. 08. 28. " http://dx.doi.org/10.14382/epitoanyag-jsbcm.2014.17

\section{Abstract}

Spatial variographic analysis has been performed on rebound index data collected in-situ at the bottom surface of a concrete floor over $130 \mathrm{~m}^{2}$ of testing area. Possible use of geostatistical methods in terms of semivariogram, madogram and rodogram analysis was demonstrated. It has been revealed that the classical methods of geostatistics may be further refined for more satisfactory use in the spatial variability analysis of in-situ rebound hardness test results on concrete structures and a possible direction toward the use of empirical estimation of extremal coefficient functions is proposed.

Keywords: Structural concrete; Nondestructive testing (NDT); Rebound index; Spatial variability; Variogram

\section{Introduction}

Geostatistical methods are widely used in mining, geology, soil science, environmental science, hydrology, meteorology and recently, in engineering sciences for remote sensing, surface texture modelling, reliability and risk analysis, service life design and analysis of non-destructive testing [1-10]. The spatial variability analysis is well-described in the geostatistical literature for a long time; the reader may refer to the several textbooks available in geostatistics [11-16]. The use of the geostatistical methods for concrete structures is, however, still very much limited today [8-10].

In-situ non-destructive testing (NDT) of concrete structures may target strength estimation of structural concrete either to complete destructive testing or in the absence of drilled cores for laboratory testing [17-20]. In-situ assessment is frequently initiated by corrosion problems [21-23].

Structural concrete is a multiple-level heterogeneous composite material [24-25]. This multiple-level heterogeneity results both inherent (local) variability and spatial (regional) variability of the performance properties. Local variability can be analysed by conventional mathematical statistical methods. Analysis of regional variability needs spatial models - that are typically used in geostatistics.

\section{Scope of the studies}

In the first part of the present series of papers, inherent variability parameters were analysed corresponding to the independent test areas of a reinforced concrete slab, in terms of statistical location parameters, statistical variance parameters, statistical dispersion parameters and normality parameters [26].

In this second part, spatial variability is studied by contour plot, omnidirectional semivariogram (variogram of order 2 ), omnidirectional madogram (variogram of order 1) and omnidirectional rodogram (variogram of order 1/2).

\section{Experimental}

The experimental background was provided by the same structural element that was analysed in [26], i.e. the bottom surface of the top concrete slab of a framed, monolithic, subsoil concrete tunnel was studied, with dimensions of $25.0 \mathrm{~m} \times 7.5$ $\mathrm{m}$ and a thickness of $0.48 \mathrm{~m}$ [10]. The measuring region on the bottom surface was $22.0 \mathrm{~m} \times 6.0 \mathrm{~m}$. A total number of 42 test areas were selected for Schmidt rebound hammer testing. $\mathrm{N}$-type original Schmidt rebound hammer was used. Eleven individual rebound index readings were recorded at each test area. The measurements were performed by the same operator.

\section{Spatial variability analysis of the statistical parameters}

In a practical situation, when eventually weaker regions of structural concrete within the element are present, it can be interesting to know that at which extent and in which directions the discrepancy is present and has influence on the performance properties. Geostatistical approaches can be adapted for the analysis of spatial variation. Geostatistics deals with spatially autocorrelated data (autocorrelation = correlation between elements of a series and others from the same series separated from each other by a given interval) and usually assumes that the differences between the values of samples are determined by the relative spatial distance of the samples and the mean and variance of the differences depend only on the relative distance [13]. Different variograms are introduced in geostatistical spatial correlation analysis that plot different correlation parameters of samples as the function of the separation between two spatial locations (referred to as lag; indicated with $\mathbf{h}$ in the present paper). Empirical semivariogram can be composed by the empirical semivariances of order 2 (see Appendix). Empirical madogram can be composed by the empirical semivariances of order 1. Empirical rodogram can be composed by the empirical semivariances of order $1 / 2$. It is possible to compose omnidirectional variograms by taking into account all pairs of data in any possible relative distance, and it is possible to compose unidirectional variograms by taking those pairs of data into account that correspond to a given direction. This latter method was not applied in the present studies but would be used to find anisotropy in the 


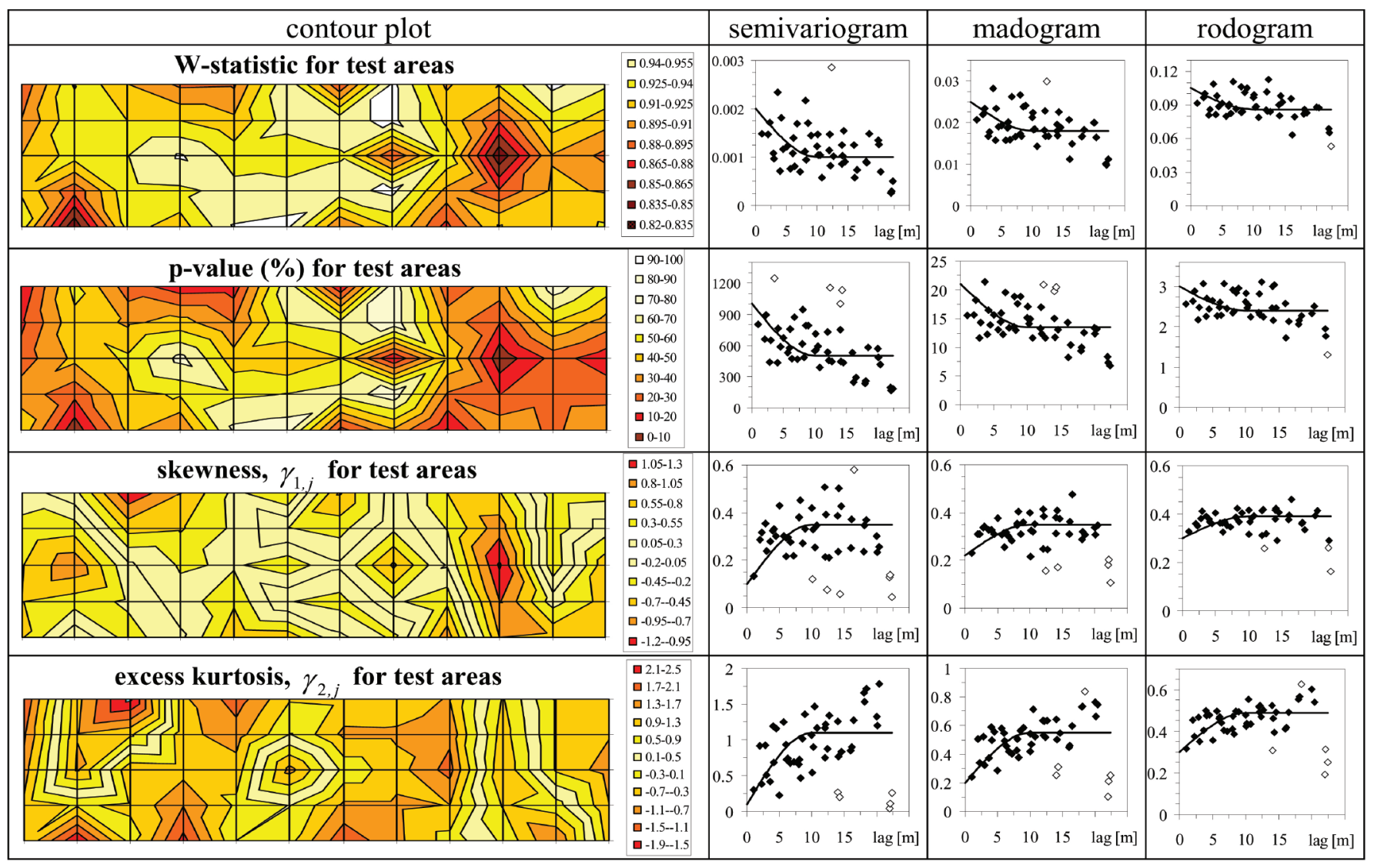

Fig. 1. Variographic analysis for the normality parameters

1. ábra Normalitási paraméterek variográfiai vizsgálata

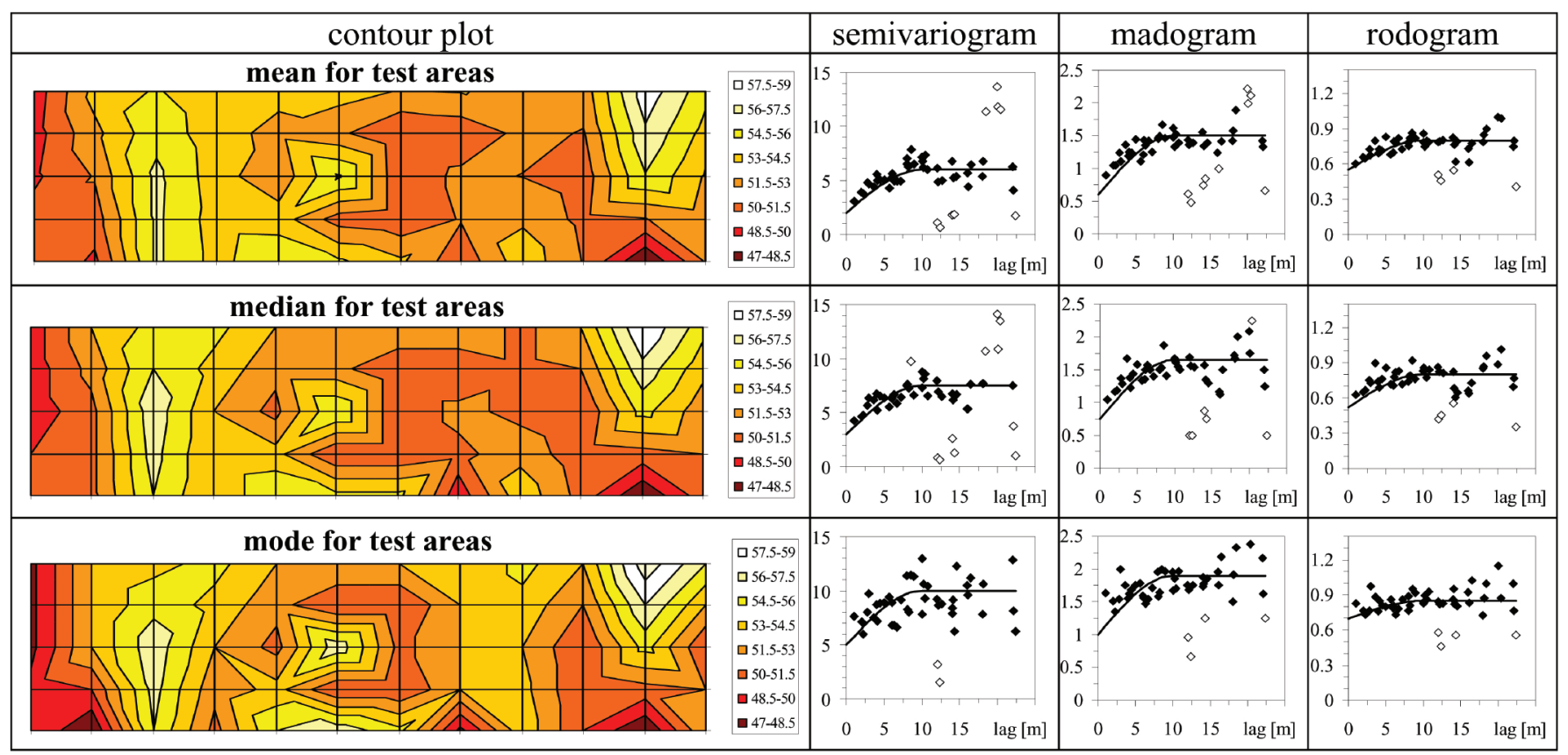

Fig. 2. Variographic analysis for the statistical location parameters

2. ábra Helyzeti statisztikai paraméterek variográfiai vizsgálata

spatial variability in a practical situation. In our nomenclature, the term variogram generally covers either semivariogram, or madogram or rodogram throughout the present paper.

If a variogram levels off (bounded) then a stationary random field can be used to model the observations [27].
According to the geostatistical modelling nomenclature, the sill is the value of the actual correlation parameter at which the variogram levels off and the range is the lag distance over which the actual correlation parameter is constant. The range distance can be referred to as correlation distance, over which 


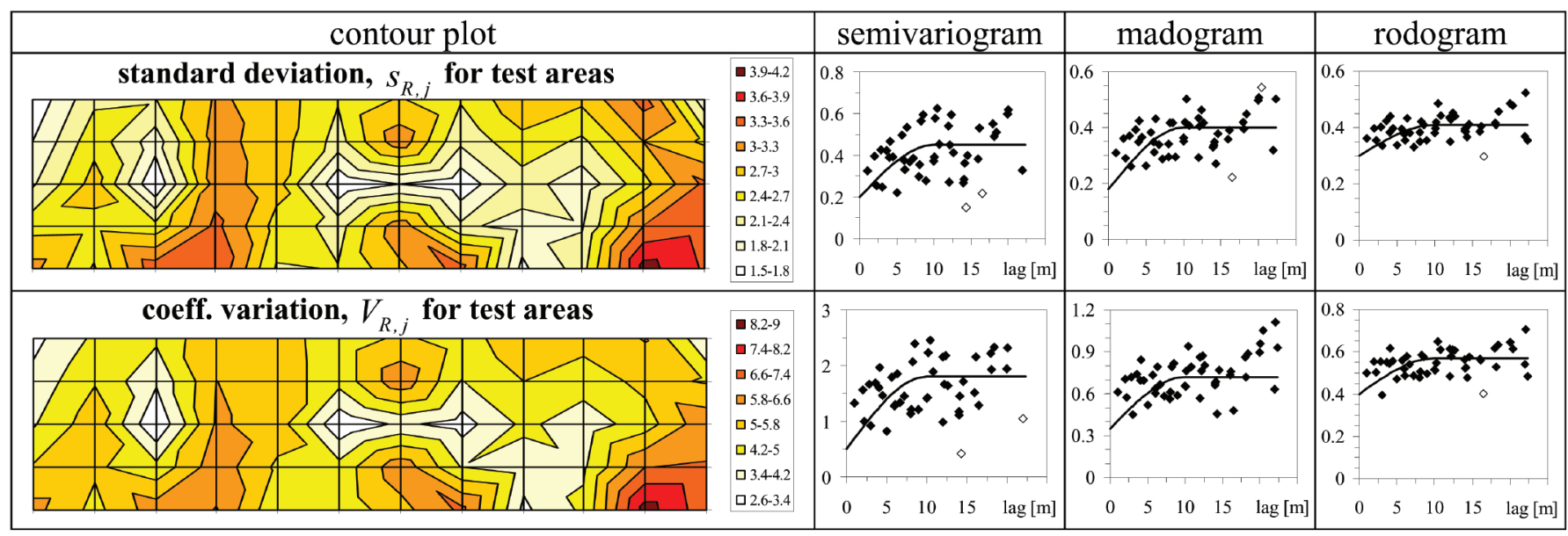

Fig. 3. Variographic analysis for the statistical variance parameters

3. ábra Variancia paraméterek variográfiai vizsgálata
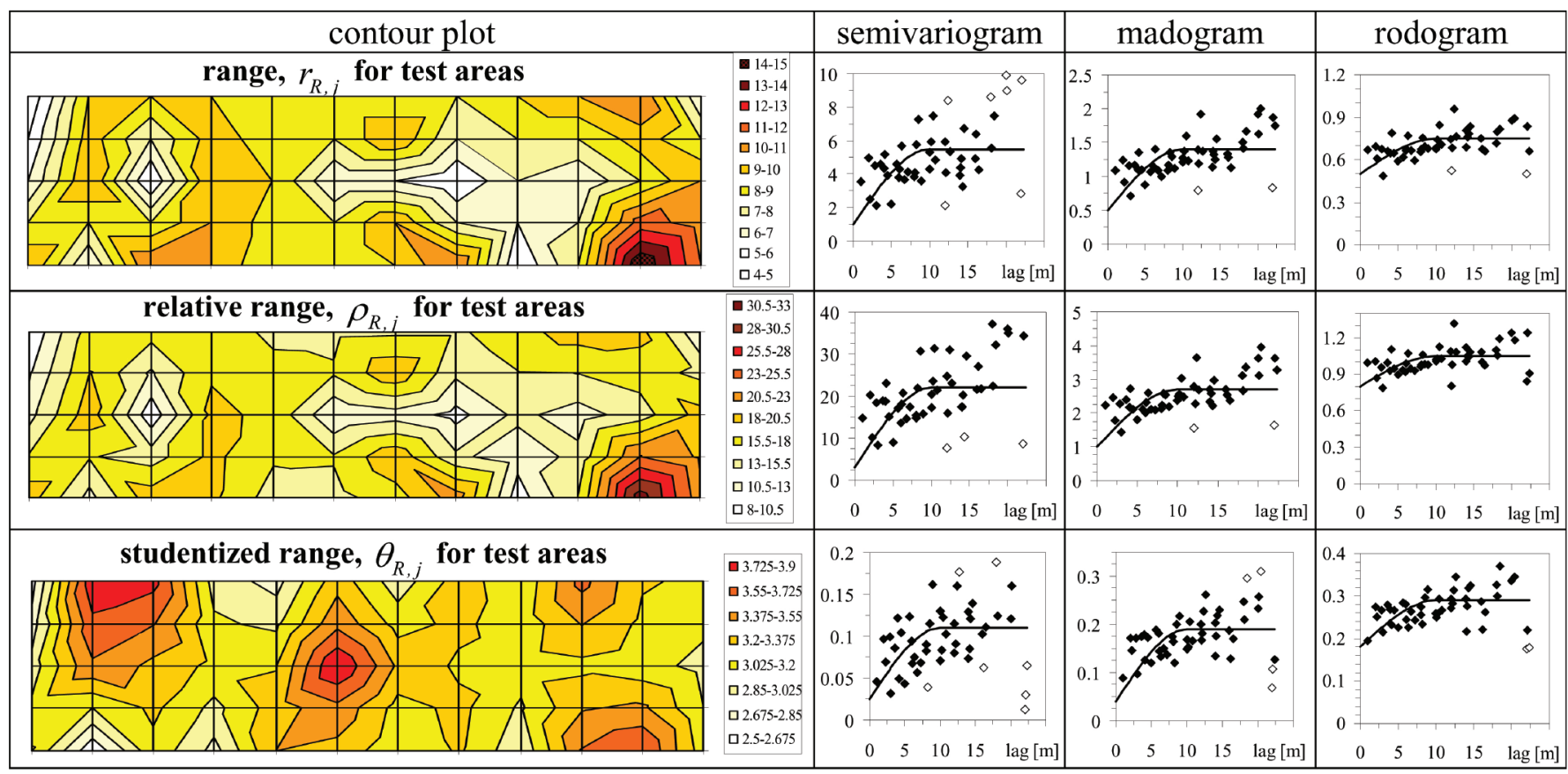

Fig. 4. Variographic analysis for the statistical dispersion parameters

4. ábra Terjedelem paraméterek variográfiai vizsgálata

lag the values of the variable are not correlated (independent). The correlation distance indicates the degree of similarity of the variable between two points as a function of the distance that separates them. The nugget is the value of the actual correlation parameter at distances smaller than the minimum lag of observations $[13,16]$. The nugget effect may provide information on strong differences in value within very short distances, or on a structural discontinuity, or on local material deterioration, or on an erroneous measurement [27].

Experimental variograms cannot be used directly for modelling and simulation. A wide range of variogram models are introduced in the literature of geostatistics. Typical models are the spherical, exponential, Gaussian, wave, nugget models $[13,16]$. Combined models are also used.

Figs. 1 to 4 summarize the empirical omnidirectional semivariograms, madograms and rodograms corresponding to the statistical parameters analysed. In the present study, the concrete slab has dimensions of $25.0 \mathrm{~m} \times 7.5 \mathrm{~m}$ of which the studied region is $22.0 \mathrm{~m} \times 6.0 \mathrm{~m}$. In geostatistics, a common rule of thumb is accepted for the maximum lag in a variogram restricted to half of the diagonal of data extent [28]. It should be noted that lag is intentionally not limited to about 12 meters since one dimension of the slab is three times larger than the other. Restricting the variograms at maximum lag about half of the diagonal of data extent would not allow the diagrams to visibly level off and the sill could not be clearly determined. It should be also noted that intentionally no filtering was applied for the calculated correlation parameters but the suspected outlier values are indicated with empty markers in the variograms. Spherical model is fitted for all the 36 variograms that is also indicated in Figs. 1 to 4. 


\section{Discussion}

The strength estimation of concrete by rebound hammer testing usually applies empirical relationships between statistical location parameters (mostly the mean and the median) and the compressive strength. It can be realized by studying the contour plots (Fig. 2) and as was shown earlier by linear correlations that the statistical location parameters are interrelated and a rather strong correlation is found between the mean and median values for the concrete floor in the present study $[10,26]$. It was also demonstrated that no correlation is found between the statistical location parameters and the statistical dispersion parameters; no correlation is found between the statistical location parameters and normality parameters; as well as no correlation is found between the statistical dispersion parameters and normality parameters [26].

It can be realized by studying the contour plots of Fig. 3 and 4 that the interrelated nature of the range and the standard deviation demonstrated earlier [26] is visible for the concrete floor in the present study.

Contour plots of Fig. 1 and 4 confirm the earlier findings [26] about the interrelated nature of the studentized range and excess kurtosis.

It can be realized in the spatial variability analysis that the semivariograms, madograms and rodograms can be constructed for all the twelve statistical parameters and all variograms are bounded and level off at a more or less clearly recognizable sill. Nugget is visible in all cases. It can be generally concluded that semivariograms are the most structured and rodograms are the least structured. The relative nugget effect (ratio of nugget and sill) is the strongest for the semivariograms and the least pronounced for the rodograms. Correlation ranges are very much similar for all types of variograms and for all the twelve statistical parameters studied. The correlation range was found to be about ten meters for the concrete floor in the present study.

The variograms constructed do not clearly demonstrate recognizable differences in the spatial variability behaviour (or trend) of the twelve statistical parameters studied, therefore, another direction for the spatial variability analysis is presented here towards the analogues of the analyses of max-stable stochastic processes.

\section{Outlook}

Skewed distributions were found to be fit with the best goodness of fit for the vast majority of frequency histograms of the local statistical parameters analysed for the concrete floor in the present study [26]. It was also demonstrated that best goodness of fit of the Fisher-Tippett (Generalized extreme value, GEV) distribution could be found for the individual rebound indices collected at the 42 individual test areas if no separation of data by location is applied [26]. Therefore, an analogue for the empirical estimation of the extremal coefficient function $\theta(\mathbf{h})$ is introduced in the present spatial variability analysis.

Extremal coefficient provides a measure of the degree of spatial dependence between locations for max-stable stochastic processes [29]. Similarly to the semivariogram that can be a tool for measuring dependence of Gaussian stochastic processes (due to the relationship with covariance), the madogram is proposed as a tool for measuring dependence in max-stable stochastic processes (due to the relationship with the extremal coefficient) [30]. It was shown that an empirical estimation of the extremal coefficient function can be constructed with the introduction of a modified madogram, the $F$-madogram $v(\mathbf{h})$, proposed for the distribution function $F$ (values of $F$-madograms range from 0 to $1 / 6$ corresponding to complete dependence and independence, respectively) [31]. The empirical estimation of the extremal coefficient function becomes:

$$
\begin{aligned}
& \theta(\mathbf{h})=\frac{1+2 \cdot v(\mathbf{h})}{1-2 \cdot v(\mathbf{h})} \\
& \text { where } v(\mathbf{h})=\frac{1}{2 N(\mathbf{h})} \sum_{i=1}^{N(\mathbf{h})}\left|F\left(\mathbf{u}_{i}+\mathbf{h}\right)-F\left(\mathbf{u}_{i}\right)\right|
\end{aligned}
$$

Since extreme value distributions were found to provide best goodness of fit for the statistical parameters tested in the present analyses, a simple analogue of the extremal coefficient function is proposed for the empirical madograms as follows:

$$
\theta^{(1)}(\mathbf{h})=\frac{1+2 \cdot \gamma^{(1)}(\mathbf{h})}{1-2 \cdot \gamma^{(1)}(\mathbf{h})}
$$

where $\gamma^{(1)}(\mathbf{h})$ is the empirical semivariance of order 1 (see Appendix).

Results are indicated in Fig. 5. It should be noted that outliers (if any) were filtered and were not plotted in the graphical representation. It can be realized - on the contrary to the quite similar semivariogram, madogram or rodogram profiles - that the performance of the proposed dependence measure $\theta^{(1)}(\mathbf{h})$ is apparently separated to quite different behaviours.

There are statistical parameters for which no trend or very weak trend is visible: this is the case for normality parameters and for statistical variance parameters. Clear linear trend is visible for the statistical dispersion parameters. An exponential variogram model can be fitted to the statistical location parameters. The relative nugget effect of the proposed dependence measure $\theta^{(1)}(\mathbf{h})$ is found to be considerably different for the mean, for the median and for the mode.

At this time it is not clear how the proposed $\theta^{(1)}(\mathbf{h})$ dependence measure can be applicable for the spatial analysis of real in-situ measurements, but it emphasizes that some more sensitive parameters may be formulated than the semivariogram, madogram and rodogram, which behaviour was not found to be satisfactorily distinctive for the statistical parameters studied in the present analyses of rebound index data collected in-situ on a concrete floor. Future research is needed in this field.

\section{Conclusions}

Spatial variability analyses were carried out on in-situ rebound hammer test results collected at the bottom surface of a concrete floor over $130 \mathrm{~m}^{2}$ of area tested. The following observations can be highlighted: 


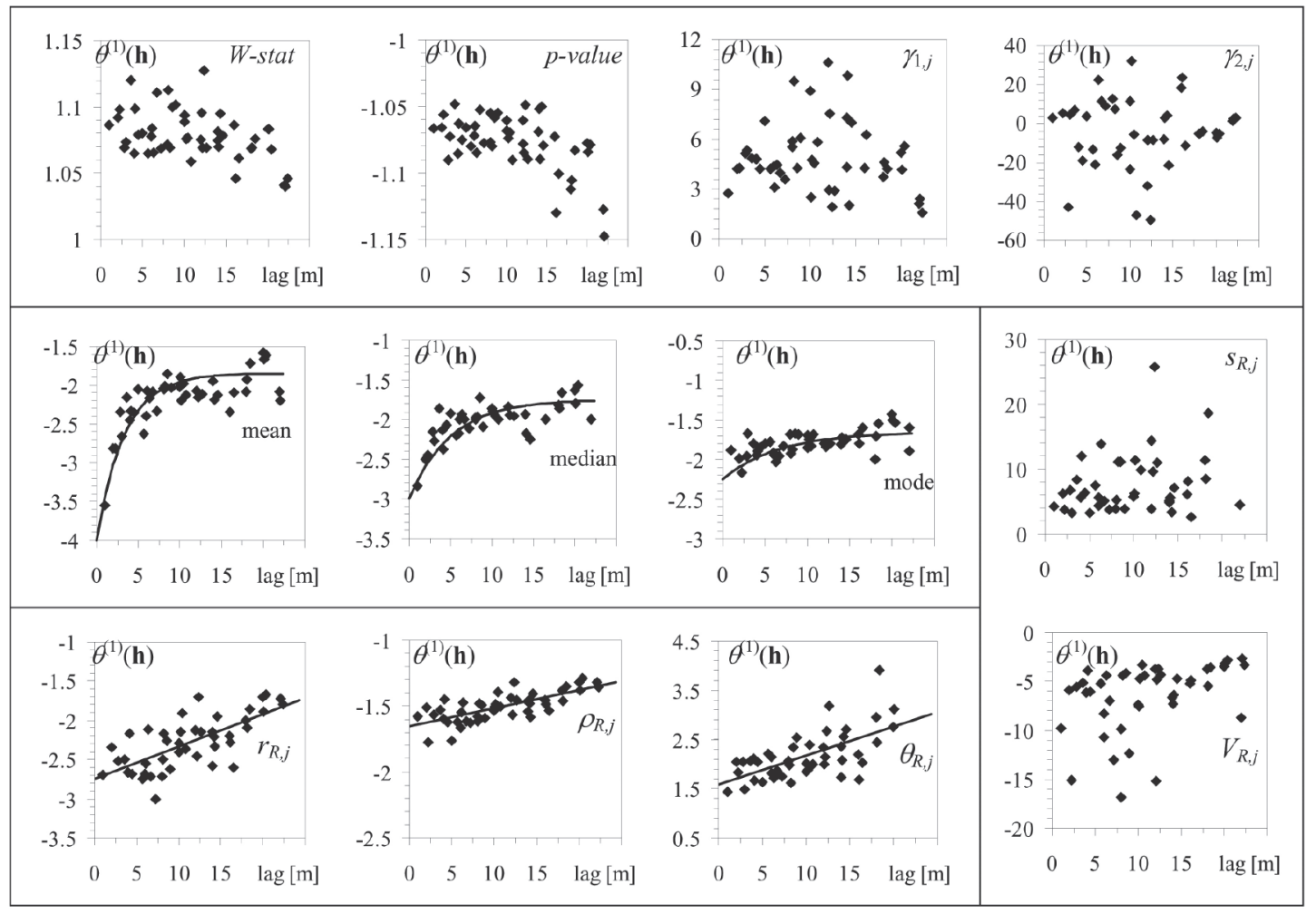

Fig. 5. Analogue for the empirical estimation of the extremal coefficient function for the statistical parameters studied

5. ábra Tapasztalati szélsőérték együttható függvény analógiájának illusztrálása a vizsgált statisztikai paraméterekre vonatkozóan

1. Semivariogram, madogram and rodogram can be successfully constructed for any statistical parameter to visualize spatial variability. Variograms always level off and nugget is clearly observed as well. It was found that restricting of the variograms at maximum lag about half of the diagonal of data extent is not practical for the geometry of the concrete floor studied.

2. It was found that semivariograms are the most structured and rodograms are the least structured. The relative nugget effect is the strongest for the semivariograms and the least pronounced for the rodograms. Correlation range was found to be about ten meters for the concrete floor in the present study, independently of the statistical parameter tested. Further studies on the influence of outlier filtering in the spatial variability analysis for rebound index data sets is addressed to future work since outliers may considerably increase both nugget and sill in variograms, as indicated in [32].

3. It was found that variograms constructed do not clearly demonstrate recognizable differences in the spatial variability behaviour for different statistical parameters, therefore, a dependence measure was introduced as an analogue for the empirical estimation of the extremal coefficient function (defined for F-madogram), with the simple adaptation of the idea to madograms. It was demonstrated that the performance of the proposed dependence measure is apparently separated to quite different behaviours; providing more sensitivity than semivariograms, madograms and rodograms.

\section{Acknowledgements}

Author gratefully acknowledges the support of the Hungarian Scientific Research Fund project "Durability and performance characteristics of concretes with novel type supplementary materials" (OTKA K 109233).

\section{References}

[1] Matheron, G.: (1971) The Theory of Regionalized Variables and its Applications. École Nationale Supérieure des Mines de Paris

[2] Goovaerts, P.: (1999) Geostatistics in soil science: state-of-the-art and perspectives. Geoderma, Vol. 89, No. 1-2, 1999, pp. 1-45. http://dx.doi.org/10.1016/S0016-7061(98)00078-0

[3] Tutmez, B. - Hatipoglu, Z.: (2007) Spatial estimation model of porosity. Computers \& Geosciences, Vol. 33, No. 4, 2007, pp. 465-475. http://dx.doi.org/10.1016/j.cageo.2006.07.008

[4] Balaguer, A. - Ruiz, L. A. - Hermosilla, T. - Recio, J. A.: (2010) Definition of a comprehensive set of texture semivariogram features and their evaluation for object-oriented image classification. Computers \& Geosciences, Vol. 36, No. 2, 2010, pp. 231-240. http://dx.doi.org/10.1016/j.cageo.2009.05.003

[5] Mlynarczuk, M.: (2010) Description and classification of rock surfaces by means of laser profilometry and mathematical morphology. International Journal of Rock Mechanics and Mining Sciences, Vol. 47, No. 1, 2010, pp. 138-149. http://dx.doi.org/10.1016/j.ijrmms.2009.09.004

[6] Stewart, M. G. - Mullard, J. A.: (2007) Spatial time-dependent reliability analysis of corrosion damage and the timing of first repair for RC structures. Engineering Structures, Vol. 29, No. 7, 2007, pp. 1457-1464. http://dx.doi.org/10.1016/j.engstruct.2006.09.004

[7] Li, J. - Masia, M. J. - Stewart, M. G., Lawrence, S. J.: (2014) Spatial variability and stochastic strength prediction of unreinforced masonry walls in vertical bending. Engineering Structures, Vol. 59, 2014, pp. 787-797. http://dx.doi.org/10.1016/j.engstruct.2013.11.031

[8] Nguyen, N. T. - Sbartaï, Z. M. - Lataste, J. F. - Breysse, D. - Bos, F.: (2013) Assessing the spatial variability of concrete structures using NDT 
techniques - Laboratory tests and case study. Construction and Building Materials, Vol. 49, 2013, pp. 240-250.

http://dx.doi.org/10.1016/j.conbuildmat.2013.08.011

[9] Gomez-Cardenas, C. - Sbartaï, Z. M. - Balayssac, J. P. - Garnier, V. - Breysse, D.: (2012) Spatial sampling optimization of non-destructive testing measurements $31^{\text {èmes }}$ Rencontres Universitaires de l'AUGC, ENS Cachan, 29-31 May 2013. http://augc2013.ens-cachan.fr/Data/Articles/Contribution1187.pdf

[10] Borosnyói, A. - Szilágyi, K.: (2013) Studies on the spatial variability of rebound hammer test results recorded at in-situ testing. ÉpítőanyagJSBCM, Vol. 65, No. 4, 2013, pp. 102-106 http://dx.doi.org/10.14382/epitoanyag-jsbcm.2013.19

[11] Cressie, N. A. C.: (1993) Statistics for Spatial Data. John Wiley \& Sons ISBN 978-0-471-00255-0

[12] Chilés, J. P. - Delfiner, P.: (1999) Geostatistics - Modeling Spatial Uncertainty. John Wiley \& Sons ISBN 0-471-08315-1

[13] Clark, I.: (2000) Practical Geostatistics. Geostokos Limited ISBN 97809548911-1-4

[14] Wackernagel, H.: (2003) Multivariate Geostatistics - An Introduction with Applications. Springer ISBN 978-3-662-05294-5

[15] Diggle, P. - Ribeiro, J. P.: (2007) Model-based Geostatistics. Springer ISBN 978-0-387-48536-2

[16] Webster, R., Oliver, M. A. (2007) Geostatistics for Environmental Scientists. John Wiley \& Sons ISBN 978-0-470-02858-2

[17] Breysse, D. - Martinez-Fernandez, J. L.: (2013) Assessing concrete strength with rebound hammer: review of key issues and ideas for more reliable conclusions. Materials and Structures, Vol. 46, 2013, Published online: 25 July 2013 http://dx.doi.org/10.1617/s11527-013-0139-9

[18] Vona, M. - Nigro, D.: (2013) Evaluation of the predictive ability of the in situ concrete strength through core drilling and its effects on the capacity of the RC columns. Materials and Structures, Vol. 46, 2013, Published online: 23 November 2013 http://dx.doi.org/10.1617/s11527-013-0214-2

[19] Antonaci, P. - Bocca, P. - Grazzini, A.: (2006) In situ determination of toughness indices of fibre reinforced concrete. Materials and Structures, Vol. 39, pp. 283-290. http://dx.doi.org/10.1617/s11527-005-9003-x

[20] Masi, A. - Chiauzzi, L.: (2013) An experimental study on the withinmember variability of in situ concrete strength in RC building structures. Construction and Building Materials, Vol. 47, 2013, pp. 951-961. http://dx.doi.org/10.1016/j.conbuildmat.2013.05.102

[21] Long, A. E. - Henderson, G. D. - Montgomery, F. R.: (2001) Why assess the properties of near-surface concrete? Construction and Building Materials, Vol. 15, No. 2-3, 2001, pp. 65-79. http://dx.doi.org/10.1016/S0950-0618(00)00056-8

[22] Villagrán Zaccardi, Y. A. - Bértora, A. - Di Maio, A. A.: (2013) Temperature and humidity influences on the on-site active marine corrosion of reinforced concrete elements. Materials and Structures, Vol. 46, 2013, pp. 1527-1535 http://dx.doi.org/10.1617/s11527-012-9994-z

[23] Tay, D. C. K. - Tam, C. T.: (1996) In situ investigation of the strength of deteriorated concrete. Construction and Building Materials, Vol. 10, No. 1, 1996, pp. 17-26. http://dx.doi.org/10.1016/0950-0618(95)00057-7

[24] Pekár, G.: (2013) Simple basic model for concrete and its application. Part 2 - Factors that influence compressive strength and drying shrinkage. Építőanyag-JSBCM, Vol. 65, No. 3, 2013, pp. 76-84. http://dx.doi.org/10.14382/epitoanyag-jsbcm.2013.15

[25] Pekár, G.: (2013) Simple basic model for concrete and its application. Part 3 - Factors affecting consistency, material balance equations and mix design. Építőanyag-JSBCM, Vol. 65, No. 4, 2013, pp. 118-126. http://dx.doi.org/10.14382/epitoanyag-jsbcm.2013.22

[26] Borosnyói, A.: (2014) Variability case study based on in-situ rebound hardness testing of concrete. Part 1. Statistical analysis of inherent variability parameters. Építőanyag-JSBCM, Vol. 66, No. 3, pp. 85-91. http://dx.doi.org/10.14382/epitoanyag-jsbcm.2014.16

[27] Breysse, D. - Marache, A.: (2011) Some Estimates on the Variability of Material Properties. In: Construction Reliability Safety, Variability and Sustainability (Eds. Baroth, J., Schoefs, F., Breysse, D.). John Wiley \& Sons ISBN 978-1-84821-230-5

[28] Coombes, J.: (2005) Handy Hints For Variography - Guidelines for variogram analysis. Snowden Associates Pty Ltd.
[29] Ribatet, M.: (2009) A User's Guide to the SpatialExtremes Package. École Polytechnique Fédérale de Lausanne Switzerland

[30] Cooley, D. S.: (2005) Statistical Analysis of Extremes Motivated by Weather and Climate Studies: Applied and Theoretical Advances. PhD thesis. University of Colorado

[31] Cooley, D. S. - Cisewski, J. - Erhardt, R. J. - Jeon, S. - Mannshardt, E. Omolo, B. O. - Sun, Y.: (2012) A Survey of Spatial Extremes: Measuring Spatial Dependence and Modeling Spatial Effects. REVSTAT-Statistical Journal, Vol. 10, 2012, pp. 135-165. ISSN 1645-6726

[32] Oliver, M. A. - Webster, R.: (2014) A tutorial guide to geostatistics: Computing and modelling variograms and kriging. Catena, Vol. 113, 2014, pp. 56-69. http://dx.doi.org/10.1016/j.catena.2013.09.006

\section{Appendix. Formulae}

The following regional statistical measures were calculated for the spatial variability during the present analyses:

empirical semivariance of order 2:

$\gamma^{(2)}(\mathbf{h})=\frac{1}{2 N(\mathbf{h})} \sum_{i=1}^{N(\mathbf{h})}\left[f\left(\mathbf{u}_{i}+\mathbf{h}\right)-f\left(\mathbf{u}_{i}\right)\right]^{2}$

empirical semivariance of order 1 :

$\gamma^{(1)}(\mathbf{h})=\frac{1}{2 N(\mathbf{h})} \sum_{i=1}^{N(\mathbf{h})}\left|f\left(\mathbf{u}_{i}+\mathbf{h}\right)-f\left(\mathbf{u}_{i}\right)\right|$

empirical semivariance of order $1 / 2$ :

$\gamma^{(1 / 2)}(\mathbf{h})=\frac{1}{2 N(\mathbf{h})} \sum_{i=1}^{N(\mathbf{h})}\left|f\left(\mathbf{u}_{i}+\mathbf{h}\right)-f\left(\mathbf{u}_{i}\right)\right|^{1 / 2}$

where:

u vector of spatial coordinates (with 2D components $x$ and $y$ ),

$f(\mathbf{u}) \quad$ variable under consideration as a function of spatial location

h lag vector representing separation between two spatial locations,

$f(\mathbf{u}+\mathbf{h})$ lagged value of variable under consideration,

$N(\mathbf{h}) \quad$ the number of data pairs separated by lag $\mathbf{h}$.

Local statistical measures were defined in Part 1. of present series of papers.

$\underline{\text { Ref.: }}$

Borosnyói, Adorján: Variability case study based on in-situ rebound hardness testing of concrete. Part 2.

Építőanyag - Journal of Silicate Based and Composite Materials, Vol. 66, No. 4 (2014), 94-99. p. http://dx.doi.org/10.14382/epitoanyag-jsbcm.2014.17

\section{Esettanulmány betonszerkezet helyszíni keménységméréséről}

2. rész. A mérőhelyek közötti változékonyság statisztikai elemzése

A cikk egy vasbeton födém alsó felületének $130 \mathrm{~m}^{2}$-es szakaszán végzett, helyszíni Schmidt-kalapácsos vizsgálatok eredményeinek statisztikai elemzését mutatja be. A mérôhelyek közötti változékonyság statisztikai paramétereinek elemzése és az egyes paraméterek közötti korreláció vizsgálata történik meg. Bemutatásra kerül, hogy a vizsgálat alá vont statisztikai jellemzôkre elkészíthetố olyan félvariogram, madogram és rodogram, amely szférikus modellel modellezhetô. A cikk ismertet egy új eljárást a tapasztalati szelsőérték együttható függvény analogiájaként megfogalmazott variográfiai elemzésre.

Kulcsszavak: betonszerkezet; roncsolásmentes vizsgálat; keménység; visszapattanási érték; mérôhelyek közötti változékonyság; variogram 